Reprod. Nutr. Dévelop., 1980, 20 (5 A), 1439-1459.

\title{
A comparative study of the development of the fetal testis and ovary in the monkey (Macaca fascicularis)
}

\author{
par J.P. FOUQUET, D. C. DANG* \\ Laborafoire de Physiologie de la Reproduction des Vertébrés, Université Paris VI, \\ 4, place Jussieu, 75230 Paris Cedex 05. \\ * Laborafoire d'Anafomie, U. E. R. Biomédicale, 45, rue des Saints-Pères, 75270 Paris, \\ ef Station de Physiologie animale, I. N. R. A., 78350 jouy-en-josas, France.
}

Summary. The gonadal development of the Macaca fascicularis fetus was studied between 37 and 118 days on serial semi-thin and thin sections. The testis and the ovary began to differentiate at the same age (37 days); the definitive architecture of the testis was acquired at 43 days, while a cortex and a medulla did not form in the ovary until 55 to 60 days. In spite of the time-lag and the divergent development, the testis and the ovary evidenced three comparable stages; the main event of these stages was the centrifugal role of the mesonephros.

The first stage (37-43 days) included the centrifugal and antero-posterior differentiation of the sex cord anlages from the mesonephric mesenchyme in contact with the proximal loops of the anterior tubules (for a detailed study see Dang and Fouquet, 1979).

From 43 days (second stage), a remainder of the mesonephric mesenchymal blastema of the gonad supplied the rete system. The mesonephric tubules fused secondarily with that system which was connected to the sex cords. Whereas in the testis, the rete blastema did not play a direct role in organizing testicular structures, but only in forming excretory pathways, in the ovary, it invaded the medulla (whose initial sex cords degenerated) and penetrated to the ovigerous cords of the cortex. The rete ovarii blastema was probably the major source of periovocyte cells.

The third stage included the differentiation of a steroidogenic interstitial tissue (from 50 days in the testis; at about 60 days in the ovary) and is further involution; these processes were similar in both sexes.

Observation of the fine structure showed the development of the male and female gonocytes to be the same ; the prespermatogonia and the oogonia could be characterized by the formation of nuclear vacuoles. The Sertoli cells and the periovogonial cells showed the same features.

\section{Introduction.}

After a century of controversy, we are nearing a solution to the problem of gonadal differentiation, at least in mammals. Advanced a long time ago (Carlon and Stahl, 1973 ; Peters, 1976), the hypothesis of the role of the mesonephros in gonadal histogenesis, supported by Jost (1972), has just been confirmed by electron microscopy. In rats (Merchant, 1975 ; Stein and Anderson, 1979), mice (Byskov, 1978 ; Upadhyay 
et al., 1979), hamsters (Fajer ef al., 1979), sheep (Zamboni ef al., 1979) and humans (Wartenberg, 1978), tubular and/or mesenchymal mesonephric cells contribute to the formation of the sex cords in the testis and the ovary. In the monkey, Macaca fascicularis, a fine structure study has shown (Dang and Fouquet, 1979) that the process of gonadal development at the indifferent stage is the same in both sexes. The sex cord anlages, composed of mesenchymal mesonephric cells wich join the primordial gonocytes, form near the proximal loops of the anterior mesonephric tubules; their development is antero-posterior and centrifugal.

Our previous studies (Fouquet ef al., 1978 ; Dang and Fouquet, 1979) being mainly oriented to the principal phases of macaque testicular development, in the present study we wished to complete those data and compare them to the development of the ovary which has been studied only histologically (Van Wagenen and Simpson, 1965).

Using light and electron microscopy, we have tried to clarify the modalities of testicular and ovarian differentiation and to show that the role of the mesonephros and the fine structure of the cell population are similar in both sexes.

\section{Material and methods.}

Macaca fascicularis fetuses of known age (Dang, 1977a) (22 males of 37 to 82 days and 14 females of 37 to 118 days) were taken by cesarian (Dang, 1977b). Samples of the mesonephros-gonal were dissected, fixed and embedded using a previously described technique (Fouquet ef al., 1978). The serial semi-thin transversal sections were observed under light microscopy after Toluidine Blue staining and the thin sections under electron microscopy (JEM 100 B or Phillips 201C) after contrast with uranyl acetatelead citrate (Venable and Coggeshall, 1965).

\section{Results.}

A previous study (Dang and Fouquet, 1979) showed that, although the initial modalities of differentiation appeared to be identical during one week ( 37 to 43 days), testicular organization differed from that of the ovary (compare figs. 1 and 10). The 43-day testis already had a characteristic structure : the sex cords were enclosed in a

\section{PLATE ।}

FIG. 1. - General view of the anterior pole of a 43-day testis showing a thick tunica albuginea (a) surrounding the sex cords (sc) in the interstitium $\left({ }^{*}\right)$. The small rete blastema forms the contacts $(\leftrightarrow)$ between the sex cords and the mesonephric tubules $(\mathrm{m}) . \times 100$.

FIG. 2. - An higher magnification of the anterior pole of a transversally sectioned 46-day testis showing the direct contacts between the sex cords (sc) and one side of the rete blastema $(\leftarrow R \rightarrow)$; the other side of the rete blastema lies close to a mesonephric fubule $(\mathrm{m})$ but has no true contact with it on this section or on the adjacent serial sections. $\times 250$.

FIG. 3. - An early prespermatogonia (PS) in a 50-day testis encircled by the Sertoli cells (S) in a sex cord with a bosal lamina (bl). Structural differences between the germ and the somatic cells are evident. The array of rough cisternae (rer) and the nuclear vacuoles (V1, V2) are specific to prespermatogonia (V2 corresponds to a single vacuole identified on adjacent sections). $\times 8330$. 
continuous basal lamina, bedded in abundant interstitial tissue, and separated from the peripheral epithelium by a thick tunica albuginea (fig. 1). The ovary at the same age was twice as small, and had a more rudimentary structure, practically lacking the tunica albuginea and the interstitial tissue. We could see only the sex cord anlages which had a discontinuous basal lamina and were apposed to the peripheral epithelium (fig. 10).

The fine structure during the same period showed that the gonocytes (large spherical cells 10 to $15 \mu \mathrm{m}$ in diameter with a polylobed nucleus and a large reticulate nucleolus) were the same in both sexes. Their clear cytoplasm contained few organelles : some isolated cisternae of the granular endoplasmic reticulum, scaterred polysomes, a small Golgi apparatus, spherical mitochondria with tubular and lamellar cristae and rare lipid droplets. The somatic cells associated with the gonocytes were similar in the testis and the ovary, being twice as small as the germ cells and irregularly shaped. Their dense cytoplasm had more organelles and inclusions than that of the gonocytes, and contained the usual mitochondria with lamellar cristae and a centriole which always formed a cilium.

After this brief description of the organization of the early indifferent testis and ovary and of the fine structure of the cell populations, we shall treat their further development separately.

\section{1. - Testicular development.}

- Befween 43 and 50 days, testicular growth was hardly visible. The architecture of the sex cords changed little because the future Sertoli cells had not completely surrounded the gonocytes. However, some modifications in fine structure were observed : in the Sertoli cells, the endoplasmic reticulum developed into a large network, while in the gonocytes, it formed parallel arrays of 5 to 10 cisternae (fig. 3). At the end of that period of slow growth, the increase in the size of some interstitial cells and the formation of the short cisternae of the smooth endoplasmic reticulum indicated their future steroidogenic differentiation (Fouquet ef al., 1978). Finally, at the anterior pole of the testis, a remainder of the indifferent gonad blastema which had not differentiated into sex cords, formed the junction between the mesonephric tubules and the sex cords, becoming compact and voluminous (fig. 2). This region, later the rete testis, was the rete blastema.

\section{PLATE II}

FIG. 4. - In a 57-day testis the straight fubules $(\rightarrow)$ and the rete blastema $(\leftarrow R \rightarrow)$ form continuous structures. However the rete blastema has not yet fused with the mesonephric tubules (m). Note the Leydig cell islets (circles) between the sex cords. $\times 100$.

FIG. 5. - In a 66-doy testis, the first true connections begin to emerge $\stackrel{\rightarrow}{\rightarrow}$ ) between the mesonephric tubules $(\mathrm{m})$ and the rete blastema $(\mathrm{R})$ which is slightly open $(\rightarrow) . \times 250$.

FIG. 6. - General organization of a sex cord in a 71-day festis. There is no change in the structure of the Sertoli (S) and germ cells or in their relationships since 50 days. Note that in a thin section, most prespermatogonia $(\mathrm{pS})$ contain 1 or 2 nuclear vacuoles $(\rightarrow)$. Leydig cells $(L)$ are seen in the interstitium. $\times 2500$. 


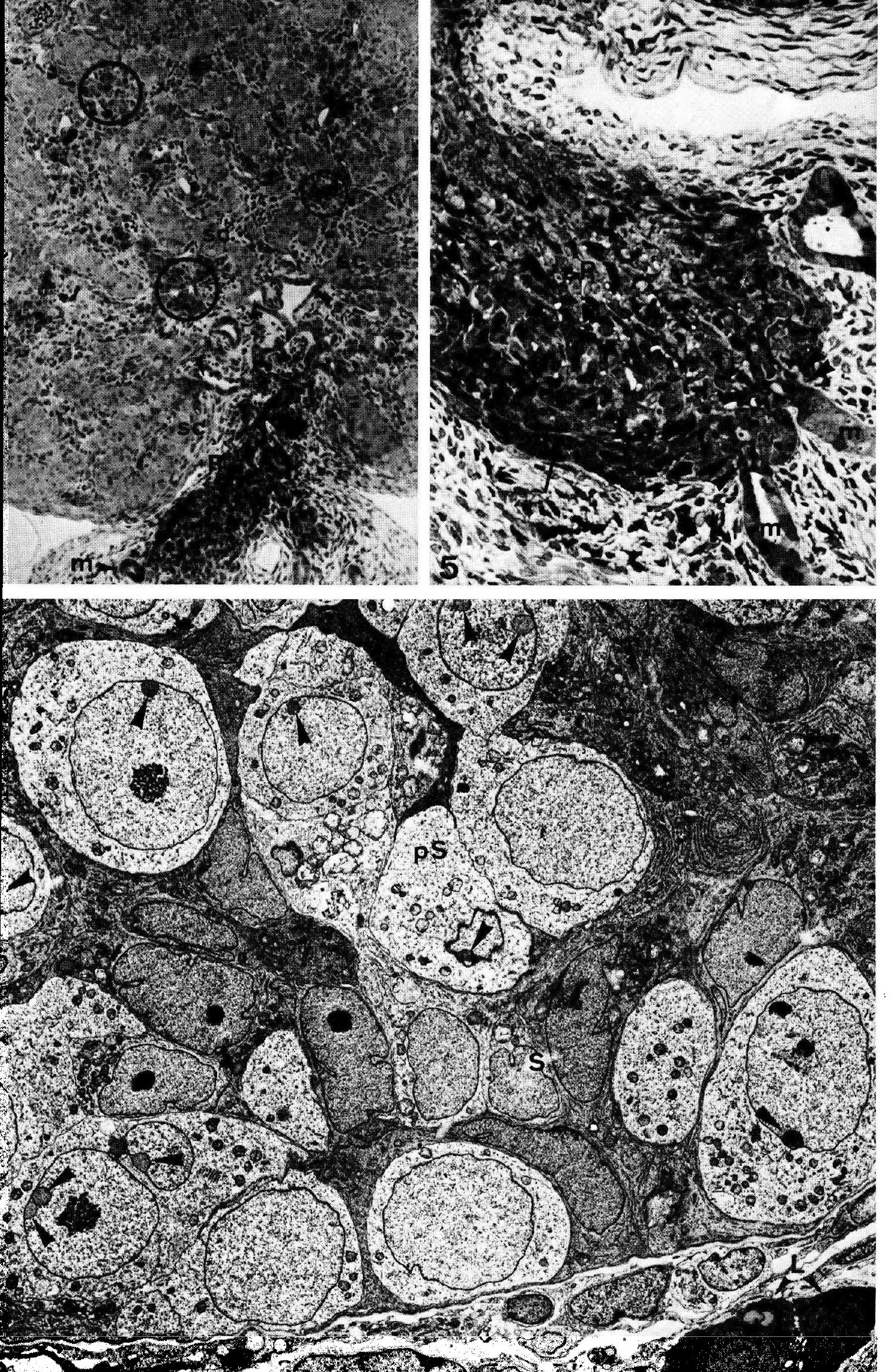


- Between 50 and 57 days, the testis and the sex cord diameter doubled (fig. 4) due to the proliferation of the germ and the somatic cells. That period of rapid development was correlated with the differentiation of the Leydig cells which, in several days, occupied 15 to 20 p. 100 of the testicular volume (Fouquet ef al., 1978). In the sex cords, the gonocytes, completely surrounded by cytoplasmic branches of Sertoli cells, no longer rested on the basal lamina. Moreover, one to two vacuoles, either adhering to the nuclear envelope or free in the nucleoplasm, were bound by a membrane having the characteristics of the internal membrane of the nuclear envelope. The germ cells, then isolated from the basal lamina of the sex cords by Sertoli cell encirclement and characterized by original nuclear structures, were no longer gonocytes but prespermatogonia, differing from the future spermatogonia diversifying later and lying on the basal lamina of the seminiferous tubules.

- Between 57 and 66 days, the growth rate was still high and testis volume, estimated by its greatest diameter, had about doubled. Leydig cell maturation at that phase was determined by the volume those cells occupied (about 30 p. 100 of the testis) and by the quality of their steroidogenic structures (Fouquet ef al., 1978). During that period, the testicular excretory pathways also began to differentiate from the rete blastema which had developed progressively from the age of 43 days. On its testicular side, the rete blastema opened into a series of tubules (the future straight tubules) apposed to the inmost ends of the sex cords (fig. 4). The walls of the mesonephric tubules then fused with the rete blastema which began to show narrowlyspaced fissures, anticipating the opening of the rete testis (fig. 5). The continuity between the mesonephric tubules (the future efferent tubules), the rete testis and the testicular structures was thus formed (figs. 5, $23 \mathrm{~A}$ ).

- During the last phase studied (between 66 and 82 days), the most striking event was the involution of the Leydig cells which, due to dedifferentiation, degeneration and phagocytosis, represented at term only 5 p. 100 of the testicular volume (Fouquet ef al., 1978). However, testicular growth continued owing to an increase in the diameter of the sex cords which were gradually surrounded by several fibroblastic layers. The prespermatogonia and the Sertoli cells, synthesizing polymorphic glycogen particles (fig. 7), continued to proliferate, and retained the same general structure and topographic connections (fig. 6). However, some specific features of the fine structure became progressively visible : the number of nuclear vacuoles in the prespermatogonia ( 2 to 3 per cell) increased at 78-82 days as did the number of parallel microtubule bundles in the Sertoli cell cytoplasm (fig. 8). Finally, rudimentary junc-

PLATE III

FIG. 7. - 71-day testis. Prespermatogonia (PS) and Sertoli cells (S) synthesize glycogen particles which have been specifically evidenced by the periodic acid-thiocarbohydrazide-Ag proteinate method of Thiery (1967). $\times 20800$.

FIG. 8. - Part of a Serfoli cell (S) in a 82-day testis, showing a cilium (Ci) and numerous obliquely or transversally sectioned microtubules (circles). pS : prespermatogonia. $\times 40000$.

FIG. 9. - A rudimentary desmosome-like junction $(\rightarrow)$ between a prespermatogonia (pS) and a Sertoli cell $(S)$ in a 78-day testis. $\times 16700$. 
tions, which were rare in the previous phases, often joined the prespermatogonia and the Sertoli cells. These junctions (fig. 9) looked like rudimentary spot desmosomes (Staehelin and Hull, 1978) with cytoplasmic bundles of filaments parallel to the plasma membrane but lacking specialization in the intercellular space.

\section{2. - Ovarian development.}

- Between 40 and 55 days, ovarian growth was imperceptible and its architecture did not change. The structure of the germ cells and the associated somatic cells was also unchanged (fig. 12). This long latency phase of the indifferent ovary was only distinguished by the formation of a more definite junction between the anterior pole of the mesonephros and that of the ovary. That region was a remainder of the gonadal blastema which had not differentiated into sex cords adhering to the mesonephric tubules and apposed to the ovarian cord anlages (figs. 10,11). Based on its further development, that region was called the rete ovarii blastema.

- Between 55 and 75 days, growth and differentiation began again, producing an ovarian architecture characterized by the presence of a « cortex » and a « medulla » (fig. 13). Cell multiplication intensified, particularly that of the gonocytes. Mitosis was counted in about 1000 randomly selected germ cells, indicating that mitotic activity had increased fourfold between 60 and 70 days. As proliferation was more intense in the ovarian periphery, we observed the formation of a thick cortical area (figs. 13, 14, 15, 16), roughly festooned with a few capillaries which penetrated it. In those cortical ovigerous cords, the ratio of somatic cells to gonocytes dropped to about 2 (figs. 14, 16), the gonocytes often being arranged in isochronous groups according to the stages of mitosis. The irregularly shaped cortical area (the future ovarian cortex) represented a second generation of sex cords. The first generation, formed during the indifferent period, then occupied a more central position in the future ovarian medulla ; they were apposed to the cortical cords, had a higher somatic cell-gonocyte ratio (about 5), were thin, and branched into a vascularized interstitium (fig. 11).

While the ovarian structure changed, its connection with the mesonephros was also modified. The atrophied walls of the mesonephric tubules fused with the blastema

\section{PLATE IV}

FIG. 10. - Anterior pole of a 43-day ovary. The sex cord (sc) anlages are apposed to a mesonephric fubule $(\mathrm{m})$ but the continuties are not visible on this section or on the adjacent serial sections. Note the poor interstitium $\left(^{*}\right)$ as compared to a testis of the same age (fig. 1). $\times 250$.

FIG. 11. - A rudimentary rete blastema $(\leftarrow-R \rightarrow)$ connects the anterior pole of a 47-day ovary to the atrophic mesonephric tubules $(\mathrm{m})$ whose diameter is reduced (compare with fig. 8 ) but true contacts are not yet established. $\times 250$.

FIG. 12. - 47-day ovary : the sex cord anlages are still poorly organized and surrounded by only traces of a basal lamina $(\rightarrow)$, chiefly in the interior of the ovary. The gonocytes $(G)$ are not encircled by the prefollicular cells (pfc), but these two cell types have the same structures as those of the germ and somatic cells of $a$ testis of the same age. $\times 6400$. 
of the rete ovarii which became a large compact mass penetrating from the front to the back of the ovary (figs. 15, $23 \mathrm{~B}$ ). A continuity between the mesonephric fubules, the rete blastema and the medullary and cortical sex cords was thus established (figs. 15, 20, 23 B). Continuous basal laminae were observed in these compartments (figs. 17, 20), except in the most peripheral areas of the ovary.

The topographic changes were accompanied by cellular differentiation. Some steroidogenic cells, occupying 1 p. 100 of the ovarian volume at 65 to 70 days and about 2 p. 100 at 75 days, differentiated in the medullary interstitium (figs. 16, 18) as in the 50-57-day testis. They were equipped with the characteristic organelles (predominant smooth endoplasmic reticulum associated with lipid droplets and mitochondria with tubular cristae) (fig. 18), and appeared alone, then in scattered groups of 5 to 10 cells near the capillaries. In the gonocytes, the endoplasmic reticulum developed to form a parallel array of 5 to 10 cisternae and some nuclear vacuoles containing fibrillar material (figs. 14, 17) formed from the internal membrane of the nuclear envelope as in the prespermatogonia. These modified germ cells, about to enter meiosis, were the oogonia. Like the rete ovarii cells (fig. 20) which had no distinctive characteristics, the perioogonial cells maintained the same structure and basic connections with the oogonia (incomplete envelopment and absence of specialized junctions).

Although the invasion of the rete ovarii blastema and the proliferation and differentiation of the ovarian cells were the main events of the 55 to 75-day period, many oogonia and associated somatic cells autolysed. This type of degeneration was particularly noticeable in the inner cortex and medulla.

- The 75 to 118-day period was characterized by the onset of meiosis and its gradual extension to most oogonia. The first leptotene oocytes were seen alone in groups of oogonia of the inner cortex at 75 to 80 days; the onset of meiosis was then transmitted, in an irregular centrifugal wave, to the rest of the cortex. Oocytes, mostly in zygotene and pachytene stages, occupied about $2 / 3$ of the cortex at about 95 days and almost all the cortex at 118 days. The scattered oogonia then formed only a simple layer under the peripheral epithelium (fig. 21), and a few still persisted infrequently in the inner cortex. Concomitantly, the degenerating sex cords of the medulla were replaced by detached fragments of the cortex which formed groups of primordial follicles (fig. 22), enveloped by a common basal lamina. Those follicles, which had already developed into primary follicles at 118 days, then separated from the others.

PLATE V

FIG. 13. - The specific organization of the ovary begins to emerge at about 60 days. The cortical zone (C) is composed of thick cords, containing germ cells, separated by a few interstitial cells and showing mitotic activity $(\rightarrow)$; the medullary zone $(M)$ includes thinner cords in a large interstitium invaded by the rete blastema $(R) . \times 250$.

FIG. 14. - Electron microscopic observation of the cortical zone of the same 60-doy ovary. The cords are still poorly organized, the fine structure of the prefollicular somatic cells and their contacts with the germ cells have not changed since 40 days. On the contrary, the development of nuclear vacuoles $(\rightarrow)$ in some germ cells defines them as oogonia $(0 \mathrm{~g})$. li : lipid droplets. $\times 2600$. 
The period of gradual induction of meiosis was accompanied by marked changes in the fine structure. The nuclear vacuoles, characterizing the oogonia, disappeared in the oocytes at the leptotene stage, and lipid droplets accumulated in the perioocyte cells (figs. 21, 22). The steroidogenic interstitial tissue, still occupying almost 2 p. 100 of the ovarian volume at about 95 days, was composed of medullary islets and isolated cells in the cortex ; it regressed and disappeared completly at about 118 days. Finally, the oocytes and the satellite cells continued to degenerate in the inner cortex and the medulla, and even in the newly formed follicles (fig. 22).

\section{Discussion.}

1. - Role of the mesonephros in gonadal archifecture.

In 1972, Jost suggested a role for the mesonephros and reported centrifugal differentiation in the rat testis. That view has now been extended to testicular and ovarian differentiation in several mammals (see references in the introduction). While early links between the mesonephros and the gonad and their development have generally indicated that the mesonephric cells supply most of the somatic cells of the sex cords, the role of the cells of the gonadal peripheral epithelium has not been excluded (Deanesly, 1975 ; Merchant-Larios, 1979). Moreover, the origin of the mesonephric cells (glomeruli, tubules, mesenchyme) is species dependent.

In Macaca fascicularis, a mesonephric mesenchymal blastema, formed against the proximal loops of the anterior mesonephric tubules, develops into sex cords in the testis and the ovary at the indifferent stage (Dang and Fouquet, 1979). In the male, the remainder of that blastema which has not differentiated into sex cords then forms the straight tubules and the blastema of the rete, later communicating with the mesonephric tubules. The direct colonization of already differentiated testicular structures by the mesonephric tubular cells thus appears highly improbable. In the female too, a remainder of the mesonephric mesenchymal blastema of the indifferent ovary deve-

\section{PLATE VI}

(75 days ovary)

FIG. 15. - General view showing a well developed corfex $(C)$, a reduced medulla $(M)$ and a growing refe blostema $(\leftarrow R \rightarrow)$. All these compartments form continuities; direct contacts between the rete blastema and the mesonephric tubules (see figs. 19, 20) are established. $\times 100$.

FIG. 16. - The cortex (C) is composed of large festooned cords with numerous oogonia (mitosis $\rightarrow$ ) separated by little interstitium (i). The atrophic (degenerating) medullary sex cords $(\mathrm{mc}$ ) are separated by a large interstitium containing islets of differentiated steroidogenic cells $(\mathrm{St}) . \times 250$.

FIG. 17. - Structural differences befween an oogonia $(\mathrm{og})$ and on ossociafed prefollicular somatic cell $(\mathrm{pfc})$; the oogonia contains mitochondria with fubular and lamellar cristae $(\rightarrow)$ and a nuclear vacuole $(v)$. A continuous basal lamina (bl) surrounds the cords. $\times 12600$.

FiG. 18. - A typical interstitial steroidogenic cell containing predominant smooth endoplasmic reticulum $(\mathrm{ser})$ associated $(\rightarrow)$ with mitochondria with fubular cristae. $\times 20000$. 
lops into the rete ovarii anlage, but forms and establishes contact with the mesonephric tubules about 10 days later than in the male. Since the mesonephric tubules-rete blastema continuities are established at the time the ovary begins to form a « cortex 》 and a « medulla», it may be that the mesonephric tubule cells join the mesenchymal cells of the rete ovarii blastema to constitute the perioocyte (follicular) cell population. Unfortunately, due to the small number of samples, and especially to the scarcity of specific cell markers such as those found in the fetal mouse (Byskov, 1979) or sheep (Zamboni ef al., 1979) gonad, we could not demonstrate a relationship between the mesonephric tubule cells and the perioocyte cells. Although this point remains obscur, it does not weaken the hypothesis of the role of the mesonephros in ovarian or festicular development or the principle of centrifugal differentiation.

This concept of the process of gonadal differentiation, which poses no problem for the festis in the crab-eating macaque (Macaca fascicularis), must be interpreted with care in studying the ovary since the formation of the ovarian cortex results mainly from an intense multiplication of the peripheral oogonia. This cortical proliferation is usually thought to be a centripetal development of second generation or ValentinPflüger's cords. There is no contradiction between the conventional centripetal theories and the more recent centrifugal ones. After beginning centrifugal differentiation, followed by a prolonged phase of latency, the indifferent ovary enters a period of transition during which the two morphogenetic processes (the centripetal growth of the ovigerous cortex and the centrifugal growth of the rete ovarii blastema) are opposed. In the region where these two areas meet, the medulla, occupied by first generation sex cords, becomes sterile owing to massive degeneration.

\section{2. - Similarities between testicular and ovarian cell populations.}

a) Germ cells. - The male and female gonocytes of Macaca fascicularis were identical at the indifferent gonad stage and the development of their fine structure was absolutely superposable as long as meiosis had not been triggered. Their main morphological characteristics have been found in both sexes of all the mammals studied : mice (Odor and Blandau, 1969), rats (Mauger and Clermont, 1974 ; Merchant-Larios, 1976), rabbits (Gondos and Conner, 1973), pigs (Pelliniemi, 1975), humans (Ruby et al., 1970 ; Gondos and Hobel, 1971 ; Fukuda ef al., 1975 ; Fujimolo et al., 1977 ; Gould and Bernstein, 1979) and rhesus monkeys (Baker and Franchi, 1972). On the other hand, owing to the lack of cytoplasmic bridges and to the differentiation of nuclear

\section{PLATE VII}

FIG. 19. - In a 75-day ovary, the atrophic mesonephric fubes $(\mathrm{m})$ have fused with the mesenchymal rete blastema (R). The encircled area has been enlarged in figure $20 . \times 250$.

FIG. 20. - The mesonephric tubular cells (mc) and the rete cells (Rc) form a continuous structure, surrounded by a common basal lamina $(\rightarrow)$ connected to the medullary and cortical sex cords (see fig. 15). These cells could represent the future population of follicular cells but they are practically devoid of specific characters giving a clue to their fate. $\times 11250$. 
vacuoles containing fibrillar material, the prespermatogonia and oogonia of Macaca fascicularis differ from those of other species. The fact that those vacuoles, derived from the nuclear envelope, appeared during a period of proliferation and disappeared at the onset of meiosis, merits attention. If it is too early to interpret their significance, they at least serve to demarcale an exact period of development.

b) Somatic cells. - If most somatic cells of fetal gonads derive from the mesonephros, it is natural that they are identical in both sexes, at least at the onset of differentiation. In fact, they are identical at the indifferent stage (37 days) and even much later since the fine structure of the future testicular Sertoli cells at 82 days resembles that of the ovarian periovogonial cells at the same age. The small difference only concerns the quality of their connections (more or less complete encircling, absence or presence of rudimentary junctions) with the germ cells. The formation of a cilium in the somatic cells is not a significantly specific criterium since it is also found in the Leydig cells (Fouquet ef al., 1978) and in the cells of the peripheral epithelium.

The steroidogenic interstitial cells (Leydig cells) in the testis differentiate very early in the macaque and other mammals (see Fouquet et al., 1978). An equivalent process has been described in the ovary of mice (Pehlemann and Lombard, 1978), rats (Al Mehdi, 1979), guinea-pigs (Guraya, 1977) and humans (Gondos and Hobel, 1973 ; Stegner ef al., 1976). In Macaca fascicularis, the steroidogenic interstitial cells of the fetal ovary are similar to the Leydig cells (Fouquet ef al., 1978) as concerns their mesenchymal origin and the development of their fine structure : after a period of differentiation, these cells retain their characteristics during a phase of maturation and then degenerate. However, their differentiation occurs earlier and is more intense in the testis than in the ovary because they occupy up to $30 \mathrm{p} .100$ of the testicular volume between 57 and 66 days as against 2 p. 100 of the ovarian volume between 75 and 95 days.

Testosterone secretion by the fetal Leydig cells and its role in the differentiation of the male genital tract are well known (see Jost et al., 1973). Assays of fetal plasma testosterone in the macaque (Resko ef al., 1973 ; Dang and Meusy-Dessolle, 1979) and the guinea-pig (Rigaudière, 1977), for example, agree with microscopic data confirming that the testis passes through a temporary steroidogenesic crisis. The morphological similarities between the fetal testis and ovary suggest that the ovary should also evidence a temporary steroid surge. This hypothesis is reinforced by the recent discovery of estradiol secretion during a short period of ovarian differentiation before the onset of meiosis in sheep (Mauléon ef al., 1977), cattle (Shemesh et al., 1978), rab-

\section{PLATE VIII}

FIG. 21. - The outer cortex, still apposed to the peripheral epithelium (pe), contains some oogonia $(\mathrm{Og})$ with nuclear vacuoles $(\rightarrow)$ and oocytes $(\mathrm{Oc}) \times 3000$.

FIG. 22. - The medulla is occupied by the newly formed primordial follicles in an interstitium devoid of steroidogenic cells. Note that an oocyte $(\mathrm{Oc})$ and a follicular cell (fc) are degenerating. li : lipid droplet. $\times 3000$. 
bits and humans (George andWilson, 1979). However, the data are still too fragmentary to reveal the correlations between structure and function, especially since the role of fetal estradiol remains to be determined.

\section{Conclusion.}

The present study again confirms the late development of the fetal ovary as compared to that of the testis (see Jost et al., 1973). After an initial period of synchronous differentiation in both sexes, the macaque ovary passes through a latency phase which maintains it in an indifferent state for 2 to 3 weeks longer than the testis. In spite of this time-lag and a progressively divergent development, the ovary passes through stages of differentiation comparable to those of the testis; the centrifugal role of the mesonephric mesenchyme is the major event of these stages. The first stage is the formation of the anlages of the sex cords which evolve into definitive cords in the testis, while they degenerate in the ovary. Rete systems, which fuse secondarily with the mesonephric tubules, comprise the second stage. The third stage includes the differentiation, then the involution of steroidogenic interstitial tissues. Moreover, cytological analysis shows many similarities in the fine structure of the germ cells and of their associates, the somatic cells.

Reçu en décembre 1979.

Accepté en mars 1980.

Acknowledgements. - This work was supported by the Délégation générale de la Recherche scientifique ef technique (DGRST), contract No 77-7-0671. The authors wish to thank Professor C. Thibault for his advice.

Résumé. Le développement de la gonade fœtale de Macaca fascicularis a été étudié entre 37 jours et 118 jours de gestation, sur coupes semi-fines sériées et sur coupes fines. La différenciation du testicule et de l'ovaire débute au même âge (37 jours), l'architecture définitive du testicule est acquise dès 43 jours alors que l'organisation caractéristique de l'ovaire avec un cortex et une médulla, ne commence que vers 55-60 jours. Malgré ce décalage temporel et une évolution différente, le testicule et l'ovaire passent par 3 étapes de développement comparables, dominées par la participation centrifuge du mésonéphros.

La première étape (37-43 jours) est la différenciation centrifuge et antéro-postérieure d'ébauches de cordons sexuels provenant du mésenchyme mésonéphrique situé au contact des anses proximales des tubes mésonéphriques antérieurs (étude détaillée in Dang and Fouquet, 1979).

\section{PLATE IX}

FIG. 23. - Organization of the fetal testis and ovary in Macaca fascicularis and their contacts with the mesonephros at the same age (75 days). AP : anterior pole of the gonad ; circles : some germ cells. The steroidogenic intersfitial tissues are not represented.

A. The blastema of the rete testis, fused with the mesonephric tubules (MT : future efferent fubules), is connected to the seminiferous cords (SC) by the straight tubules (ST). WD: Wolffian duct. ; AR : testicular artery; AL : tunica albuginea.

B. The blastema of the rete ovarii, which has fused with the mesonephric tubules (MT), is connected to the ovarian cortex (CO) through the medulla (ME). Its extensive development suggests that if may be the major source of the perioocyte cells (follicular cells). PE : peripheral epithelium. 


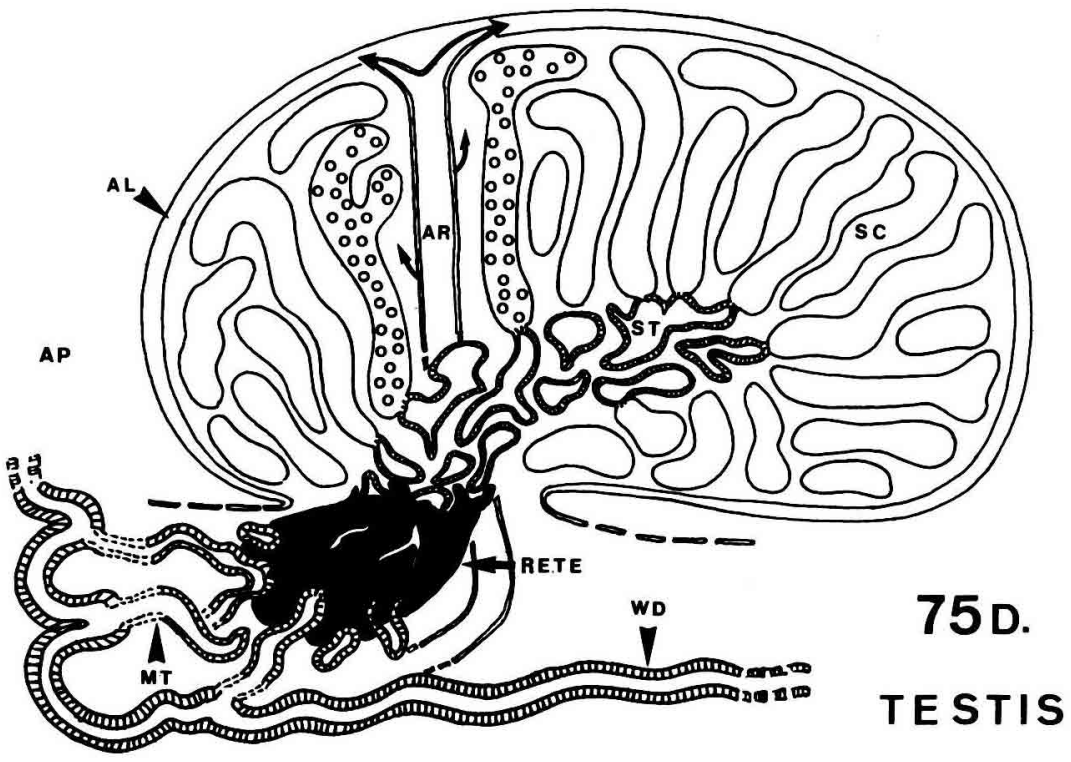

23A

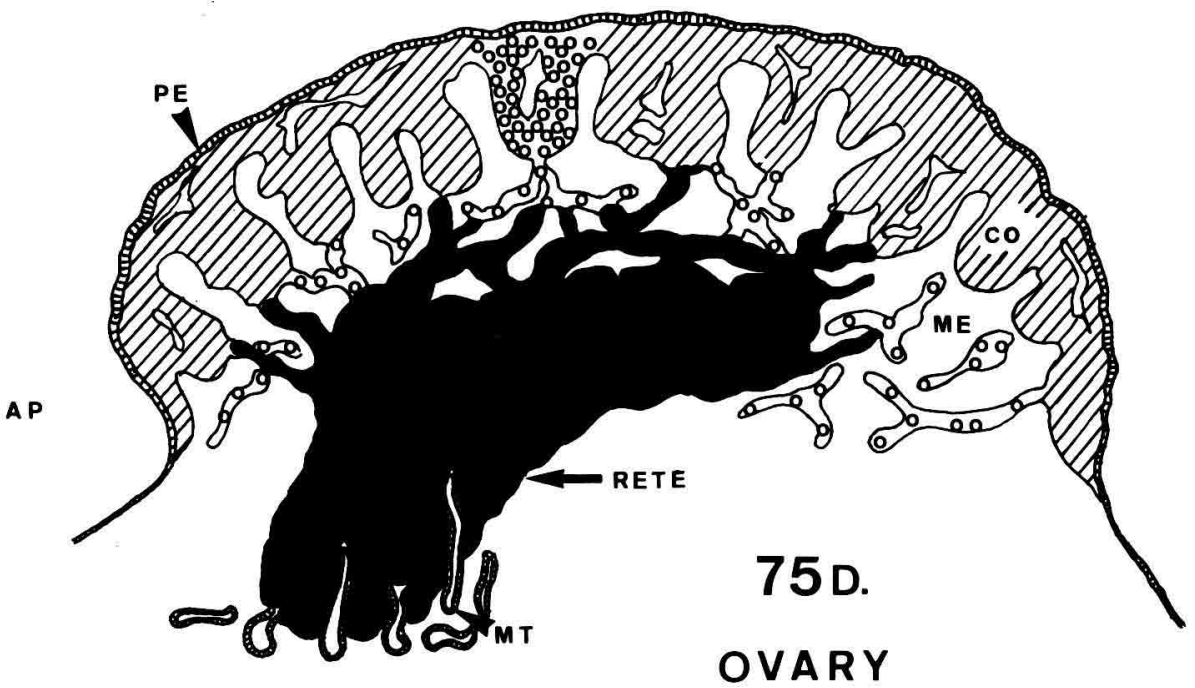


Dans la deuxième étape, à partir de 43 jours, un reste du blastème mésenchymateux mésonéphrique de la gonade fournit le système rete. Ce territoire soudé aux cordons sexuels reçoit secondairement la contribution des tubes mésonéphriques. Tandis que dans le testicule, le rete ne participe pas directement à l'organisation des structures du testicule mais seulement à celle de ses voies excrétrices, dans l'ovaire, ce rete, qui envahit la médulla de l'ovaire dont les cordons sexuels initiaux dégénèrent et qui s'avance jusqu'aux « cordons ovigères » du cortex, est probablement la source de la majorilé des cellules périovocytaires.

La troisième étape correspond à la différenciation d'un tissu interstitiel stéroidogène (à partir de 50 jours dans le testicule, vers 60 jours dans l'ovaire) et à son involution ultérieure selon un même processus dans les deux sexes.

Sur le plan ultrastructural, l'évolution des gonocytes mâles et femelles est identique. La formation de vacuoles nucléaires permet de caractériser les préspermatogonies et les ovogonies. Les cellules de Sertoli et les cellules périovogoniales possèdent les mêmes caractéristiques.

\section{References}

AL-MEHDI M. I. A., 1979. Fine structure and origin of interstitial tissue in the ovary of the pregnant rat. Acto anat., 103, 245-251.

BAKER T. G., FRANCHI L. L., 1972. The fine structure of oogonia and oocytes in the rhesus monkey (Macaca mulatia). Z. Zellforsch., 126, 53-74.

BYSKOV A. G., 1978. The anatomy and ultrastructure of the rete system in the fetal mouse ovary. Biol. Reprod., 19, 720-735.

CARLON N., STAHL A., 1973. Lespremiers stades du développement des gonades chez l'homme et les vertébrés supérieurs. Poth. Biol., 21, 903-914.

DANG D. C., 1977a. Absence of seasonal variation in the length of the menstrual cycle and the fertility of the crab-eating macaque (Macaca fascicularis) raised under natural daylight ratio. Ann. Biol. anim. Bioch. Biophys., 17, 1-7.

DANG D. C., 1977b. Resumption of menstruation and fertility after cesarian in Macaca fascicularis. Ann. Biol. anim. Bioch. Biophys., 17, 325-329.

DANG D. C., FOUQUET J. P., 1979. Differentiation of the fetal gonad of Macaca fascicularis with special reference to the festis. Ann. Biol. anim. Bioch. Biophys., 19, 1197-1209.

DANG D. C., MEUSY-DESSOLLE N., 1979. Testosterone levels in umbilical cord blood, maternal peripheral plasma and amniotic fluid of the crab-eating monkey (Macaca fascicularis). Ann. Biol. anim. Bioch. Biophys., 19, 1307-1316.

DEANESLY R., 1975. Follicle formation in guinea pigs and rabbits : A comparative study with notes on the rete ovarii. J. Reprod. Fertil., 45, 371-374.

FAJER A. B., SCHNEIDER J. O., MCCALL D., ANCES I. G., POLAKIS E. S., 1979. The induction of meiosis in vitro by ovaries of the new born hamster and its relation to the action of the rete ovarii. Ann. Biol. anim. Bioch. biophys., 19, 1273-1278.

FOUQUET J. P., DANG D. C., MEUSY-DESSOLLE N., 1978. Functional differentiation of Leydig cells in the testis of the fetal monkey (Macaca fascicularis). Ann. Biol. anim. Bioch. Biophys., 18, 1205-1221.

FUKUDA T., HEDINGER C., GROSCUTH P., 1975. Ultrastructure of developing germ cells in the fetal human testis. Cell Tiss. Res., 161, 55-70.

FUJIMOTO T., MIYAYAMA Y., FUYUTA M., 1977. The origin, migration and fine morphology of human primordial germ cells. Anat. Rec., 188, 315-330.

GEORGE F. W., WILSON J. D., 1979. The regulation of androgen and estrogen formation in fetal gonads. Ann. Biol. anim. Bioch. Biophys., 19, 1297-1306.

GONDOS B., CONNER L. A., 1973. Ultrastructure of developing germ cells in the fetal rabbit testis. Amer. J. Anat., 136, 23-42.

GONDOS B., HOBEL C. J., 1971. Ultrastructure of germ cell development in the human fetal testis. Z. Zellforsch., 119, 1-20.

GONDOS B., HOBEL C. J., 1973. Interstitial cells in the human fetal ovary. Endocrinology, 93, 736739. 
GOULD S. F., BERNSTEIN M. H., 1979. Fine structure of fetal human testis and epididymis. Arch. Androl., 2, 93-99.

GURAYA S. S., 1977. Recent advances in the morphology, histochemistry and biochemistry of the developing mammalian ovary. Int. Rev. Cytol., 51, 49-131.

JOST A., 1972. Données préliminaires sur les stades initiaux de la différenciation du testicule chez le rat. Arch. Anat. microse. Morphol. exp., 61, 415-438.

JOST A., VIGIER B., PREPIN J., PERCHELLET J. P., 1973. Studies on sex differentiation in mammals. Recent Progr. Horm. Res., 29, 1-41. Acad. Press, New York, London.

MAUGER A., CLERMONT Y., 1974. Ultrastructure des gonocytes et des spermatogonies du jeune rat. Arch. Anat. microsc. Morphol. exp., 63, 133-146.

MAULÉON P., BÉZARD J., TERQUI M., 1977. Very early and transient $17 \beta$-estradiol secretion by fetal sheep ovary. In vitro study. Ann. Biol. anim. Bioch. Biophys., 17, 399-401.

MERCHANT H., 1975. Rat gonadal and ovarian organogenesis with and without germ cells : An ultrastructural study. Develop. Biol., 44, 1-21.

MERCHANT-LARIOS H., 1976. The onset of testicular differentiation in the rat : An ultrastructural study. Amer. J. Anat., 145, 319-330.

MERCHANT-LARIOS H., 1979. Origin of the somatic cells in the rat gonad: An autoradiographic approach. Ann. Biol. anim. Bioch. Biophys., 19, 1219-1229.

ODOR D. L., BLANDAU R. J., 1969. Ultrastructural studies on fetal and early postnatal mouse ovaries. II - Cytodifferentiation. Am. J. Anat., 125, 177-216.

PEHLEMANN F. W., LOMBARD M. N., 1978. Differentiation of ovarian and testicular interstitial cells during embryonic and post-embryonic development in mice. Cell Tiss. Res., 188, 465480.

PELLINIEMI L. J., 1975. Ultrastructure of the early ovary and testis in pig embryos. Am. J. Anat., 144, 89-112.

PETERS H., 1976. Intrauterine gonadal development. Ferfil. Steril., 27, 493-500.

RESKO J. A., MALLEY A., BEGLEY D., HESS D. L., 1973. Radioimmunoassay of testosterone during fetal development of the rhesus monkey. Endocrinology, 93, 156-161.

RIGAUDIERE N., 1977. Evolution des teneurs en testostérone et dihydrotestostérone dans le plasma, le testicule et l'ovaire chez le Cobaye au cours de la vie foetale. C. R. Acad. Sci. Paris, Sér. D, 285, 989-992.

RUBY I. R., DYER R. F., GASSER R. F., SHALKO R. G., 1970. Intercellular connections between germ cells in the developing human ovary. $Z$. Zellforsch., 105, 252-258.

SHEMESH M., AILENBERG M., MILAGUIR F., AYALON N., HANSEL W., 1978. Hormone secretion by cultured bovine pre-and post-implantation gonads. Biol. Reprod., 19, 761-767.

STAEHELIN L. A., HULL B. E., 1978. Junctions between living cells. Sci. Amer., 238, 140-152.

STEGNER H. E., PAPE C., GÜNTHER P., 1976. The ultrastructure of the interstitial cells in human fetal ovaries. Arch. Gynäk., 221, 289-298.

STEIN L. E., ANDERSON C. H., 1979. A qualitative and quantitative study of refe ovarii development in the fetal rat : Correlation with the onset of meiosis and follicle cell appearance. Anat. Rec., 193, 197-212.

THIERY J.-P., 1967. Mise en évidence des polysaccharides sur coupes fines en microscopie électronique. J. Microsc., 6, 987-1018.

UPADHYAY S., LUCIANI J. M., ZAMBONI L., 1979. The role of the mesonephros in the development of the indifferent gonads and ovaries of the mouse. Ann. Biol. anim. Bioch. Biophys., 19, 1179-1196.

VENABLE J. H., COGGESHALL R., 1965. A simplified lead citrate stain for use in electron microscopy. J. Cell Biol., 25, 407-408.

WAGENEN G. Van, SIMPSON M. E., 1965. Embryology of the ovary and testis. Homo sapiens and Macaca mulatta. New Haven, U. S. A., Yale Univ. Press.

WARTENBERG H., 1978. Human testicular development and the role of the mesonephros in the origin of a dual Sertoli system. Andrologia, 10, 1-21.

ZAMBONI L., MAULÉON P., BÉZARD J., 1979. The role of the mesonephros in the development of the fetal sheep ovary. Ann. Biol, anim. Bioch. Biophys., 19, 1153-1178. 